\title{
EVALUASI PENGGUNAAN SISTEM JARING TERHADAP RESPONS PRODUKSI PENDEDERAN JUVENIL LOBSTER PASIR (Panulirus homarus) MENGGUNAKAN TEKNOLOGI RESIRKULASI
}

\author{
NET SYSTEM EVALUATION ON PRODUCTION RESPONSE DURING SPINY LOBSTER \\ (Panulirus homarus) JUVENILE REARING ON RECIRCULATING TECHNOLOGY
}

\author{
Kukuh Adiyana', Eddy Supriyono ${ }^{2)}$, Amin Pamungkas ${ }^{1)}$ dan Lolita Thesiana ${ }^{1)}$ \\ ${ }^{1)}$ Pusat Penelitian dan Pengembangan Perikanan \\ Jl. Pasir Putih I, Ancol Timur, Jakarta Utara. \\ ${ }^{2)}$ Departemen Budidaya Perairan, Institut Pertanian Bogor \\ J1. Agatis Kampus IPB Darmaga Bogor, Jawa Barat \\ E-mail: k_adiyana@yahoo.com
}

Diterima tanggal: 3 November 2016 diterima setelah perbaikan: 12 Januari 2017 disetuji tanggal: 16 Januari 2017

\begin{abstract}
ABSTRAK
Permasalahan yang sering dihadapi oleh pembudidaya lobster adalah rendahnya kelangsungan hidup karena faktor kanibalisme yang tinggi. Penggunaan sistem jaring pada budidaya pendederan lobster dimaksudkan untuk meminimalkan faktor kanibalisme, dengan memperkecil kontak antar lobster. Tujuan penelitian ini adalah untuk menganalisa pengaruh penggunaan jaring terhadap respons produksi pendederan lobster pasir Panulirus homarus.

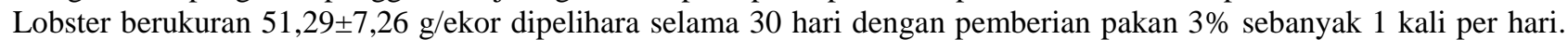
Penelitian dilakukan dengan 3 perlakuan dan 2 ulangan. Jenis perlakuan yang digunakan, yaitu selter pipa PVC sebagai kontrol (K), sekat jaring melintang \& selter pipa PVC (SJ), serta jaring keliling \& selter pipa PVC (JK). Variabel yang diamati, yaitu kondisi kualias air, Total Hemocyte Count (THC), frekuensi moulting, bobot, panjang total lobster dan kelangsungan hidup. Hasil penelitian menunjukkan bahwa penggunaan sistem jaring tidak berpengaruh terhadap respons pertumbuhan, tetapi berpengaruh positif terhadap kelangsungan hidup juvenile lobster.
\end{abstract}

Kata kunci: selter, jaring, lobster pasir, pertumbuhan, THC

\begin{abstract}
Low lobster survival rate causing the high cannibalism was an important issue faced by the farmer. The purpose of this study was to analyze and determine the effect of using nets on production response of spiny lobster (Panulirus homarus) juvenile rearing. The net used in rearing system was aimed to minimize cannibalism and to reduce body contact among lobsters. Lobster with average size 51,29 \pm 7,26 g each was reared using recirculated aquaculture system for 30 days. They were feed with fish, 3-4\% body weight/once per day. The study was conducted with three treatments and two replications. Type of treatmenst used were PVC pipe shelter as a control (K), the horizontal net divider \& PVC pipe shelter (SJ), and nets circumference inside the rearing tank \& PVC pipe shelter (JK).Variables observed during the study were water quality, total hemocyte count (THC), moulting frequency, weight mass and lobster biometry. The results showed that application of nets system, didn't influenced growth response but having positif effect on spiny lobster juvenile survival rate
\end{abstract}

Keywords: shelter, nets, spiny lobster, growth, THC

Evaluasi Penggunaan Sistem Jaring Terhadap Respons Produksi Pendederan Juvenil Lobster Pasir (Panulirus Homarus) Menggunakan Teknologi Resirkulasi - Kukuh Adiyana, Eddy Supriyono, Amin Pamungkas, dan Lolita Thesiana 


\section{PENDAHULUAN}

Lobster pasir (Panulirus homarus) merupakan komoditas perikanan bernilai ekonomis tinggi. Permintaan konsumsi lobster air laut terus meningkat dari tahun ke tahun. Menurut Drengstig dan Bergheim (2013), permintaan kebutuhan lobster air laut di pasar internasional mencapai 2000-2500 ton/tahun. Sementara itu, pasokan lobster di pasar tidak tersedia secara kontinyu. Hal ini disebabkan oleh jumlah ketersediaan lobster yang semakin menurun dan pengaruh musim dalam kegiatan penangkapan lobster di alam. Upaya budidaya lobster telah banyak dilakukan sebagai upaya untuk pemenuhan kebutuhan permintaan lobster.

Masalah yang sering dihadapi oleh pembudidaya dalam budidaya pembesaran lobster adalah rendahnya kelangsungan hidup lobster yang dibudidayakan (Thuy dan Ngoc, 2004). Ukuran benih yang tidak seragam dan adaptif juga menyebabkan kelangsungan hidup lobster yang dibudidayakan masih rendah (Adiyana, 2014). Salah satu solusi untuk mengatasi masalah tersebut, maka diperlukan kegiatan pendederan lobster.

Kegiatan pendederan lobster air laut, dapat dilakukan secara indoor. Menurut James (2007), kegiatan pendederan secara indoor memiliki kelebihan dibanding outdoor, diantaranya lebih rendahnya biaya operasional pemberian pakan dan infrastuktur. Menurut Drengstig dan Bergheim (2013), sistem resirkulasi pada pembesaran lobster dapat digunakan untuk menjaga kualitas air dan meminimumkan resiko terjadinya serangan penyakit. Sistem resirkulasi juga lebih ramah lingkungan yaitu dengan pemanfaatan kembali air yang digunakan,sehingga tidak ada penggantian air selama kegiatan budidaya. Pendederan lobster Panulirus homarus secara indoor menggunakan sistem resirkulasi, juga dimaksudkan untuk aklimatisasi benih. Proses pendederan lobster ini bertujuan untuk memberi kesempatan bagi benih lobster untuk beradaptasi dengan lingkungan yang baru, sehingga benih yang dihasilkan bersifat lebih adaptif terhadap perubahan kondisi lingkungan, dan dapat mengurangi tingkat kematian benih (Syda-Rao et al. 2010; Mohammed et al. 2010).
Lobster memiliki tingkat kanibalisme yang tinggi apabila terdapat lobster lain dalam kondisi moulting. Kondisi lobster yang moulting akan memicu lobster lain untuk memangsanya. Hal ini menyebabkan lobster memerlukan tempat bersembunyi ketika moulting (Erlania et al. 2014). Menurut Khasani (2008), selter dapat digunakan sebagai tempat persembunyian udang yang sedang mengalami moulting. Penggunaan selter diadaptasi dari tingkah laku lobster di alam yang cenderung sering bersembunyi di batu, liangliang, dan karang (Erlania et al. 2014). Menurut Adiyana et al. (2014), penggunaan selter pipa PVC pada pendederan lobster Panulirus homarus menghasilkan kelangsungan hidup dan pertumbuhan lebih baik dibanding jenis selter lainnya. Penggunaan selter dapat menekan tingkat stres lobster yang terjadi selama kegiatan budidaya. Respons stres yang lebih rendah membutuhkan energi yang lebih kecil untuk homeostasi. Lebih rendahnya energi yang digunakan untuk homeostasi selama stres, memungkinkan alokasi pemanfaatan energi metabolik investasi seperti pertumbuhan lebih baik (Hastuti et al. 2004). Menurut Jussila et al. (2001); Verghese et al. (2007); Yildiz et al. (2004), Total Hemocycte Count (THC) adalah salah satu parameter yang dapat digunakan sebagai indikator terjadinya stres pada krustasea.

Penggunaan selter untuk budidaya lobster masih memiliki kekurangan, yaitu masih memungkinkan terjadinya kontak antar lobster yang dibudidayakan. Penggunaan sistem jaring pada wadah pemeliharaan dimaksudkan untuk memberi ruang gerak yang lebih luas, sehingga kontak antar lobster dapat diminimalkan. Penelitian mengenai penggunaan sistem jaring pada wadah budidaya lobster pasir Panulirus homarus belum banyak dilakukan. Hal ini menunjukkan perlu dilakukan penelitian penggunaan sistem jaring yang efektif untuk meningkatkan produktivitas budidaya lobster. Penelitian ini bertujuan untuk menganalisa pengaruh penggunaan jaring terhadap respons produksi pendederan lobster pasir Panulirus homarus.

\section{BAHAN DAN METODE}

\section{Benih lobster}

Benih lobster yang digunakan dalam penelitian ini 
berjenis lobster pasir Panulirus homarus. Benih lobster berasal dari hasil tangkapan alam di daerah Pelabuhan Ratu, Sukabumi, Jawa Barat. Rata-rata bobot benih yang digunakan adalah $51,29 \pm 7,26$ $\mathrm{g} / \mathrm{ekor}$ dan panjang total $132,07 \pm 5,63 \mathrm{~mm} / \mathrm{ekor}$.

\section{Pakan}

Pakan yang digunakan dalam penelitian ini adalah ikan rucah dari nelayan di kawasan Ancol. Ikan rucah segar dicuci terlebih dahulu dan dipotong kecil-kecil (3-4 gram), kemudian disimpan didalam freezer.

\section{Jaring dan Selter}

Jaring yang digunakan yaitu jenis waring

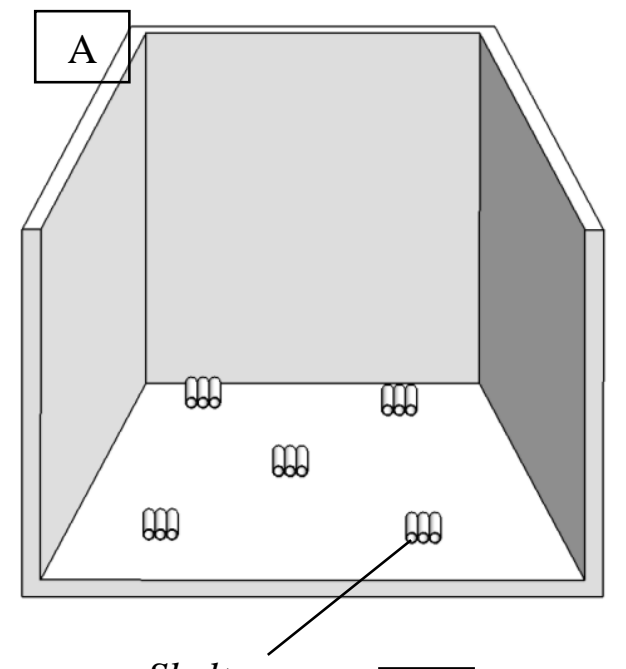

Shelter berwarna hitam. Selter yang digunakan adalah pipa PVC dengan ukuran diameter 1,5 inchi dan panjang $15 \mathrm{~cm}$. Selter diletakkan secara acak pada masing-masing perlakuan dengan rasio selter : lobster sebesar 1:3.

\section{Bak Penelitian}

Bak atau wadah budidaya dalam penelitian ini menggunakan 3 bak semen dengan ukuran 4 x $1 \mathrm{x}$ $1,1 \mathrm{~m}$. Perlakuan yang menggunakan jaring dipasang dengan dua model, yaitu dipasang mengelilingi bagian dalam bak dan dipasang sebagai sekat. Skema penempatan jarring dan selter pada masing-masing bak perlakuan dapat dilihat pada Gambar 1.

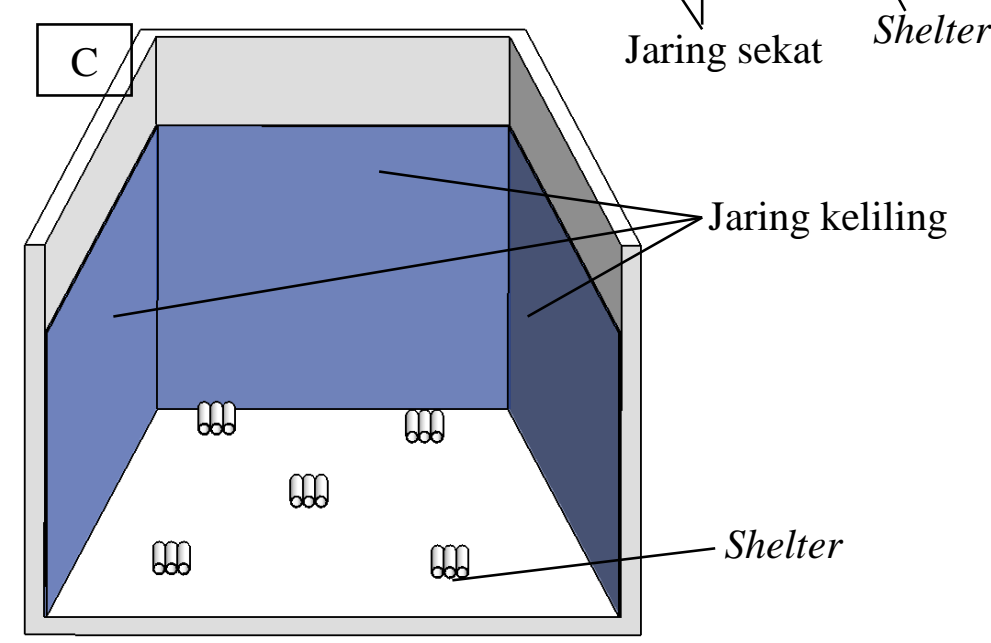

Gambar 1 Skema potongan kolam percobaan. (A) kolam tanpa jaring, (B) kolam dengan jaring bersekat, (C) kolam dengan jaring keliling.

Figure 1 Inside view of rearing tanks, (A) without nets, (B) nets partition, (C) nets lining inside the rearing tanks. 


\section{Pemeliharaan Lobster}

Lobster dipelihara dalam wadah budidaya terkontrol semi outdoor dengan dilengkapi sistem aerasi, dan sistem resirkulasi. Bak diisi air laut sebanyak 1,4 ton/bak. Selama 30 hari pemeliharaan, lobster diberi pakan 1 kali sehari dengan ikan rucah sebanyak 3-4\% dari bobot lobster. Pakan diberikan setiap petang, yaitu pukul 18.00 WIB. Padat tebar yang digunakan adalah sebesar 20 ekor $/ \mathrm{m}^{2}$.

\section{Pengolahan Kualitas Air}

Pengelolaan kualitas air pada sistem resirkulasi menggunakan skimmer protein dan filter. Pembersihan tampungan buangan pada skimmer protein dilakukan setiap hari. Bak dibersihkan dari sisa pakan setiap hari menggunakan jaring. Penambahan air tawar dilakukan secara bertahap untuk menjaga salinitas pada rentang 32-36 ppt.

\section{Pengamatan Lobster}

Lobster diamati bobot dan panjang tubuhnya setiap 10 hari sekali selama 30 hari masa pemeliharaan. Pengukuran bobot dilakukan menggunakan timbangan digital dengan ketelitian 0,01 g. Pengukuran panjang menggunakan jangka sorong dengan ketelitian $0,01 \mathrm{~mm}$.

\section{Rancangan Penelitian}

Pada penelitian ini digunakan rancangan acak lengkap (RAL) dengan 3 perlakuan dan 2 ulangan. Jenis perlakuan yang digunakan adalah selter pipa PVC sebagai kontrol (K), sekat jaring \& selter pipa PVC (SJ), dan jaring keliling \& selter pipa PVC (JK). Rasio selter : lobster yang digunakan adalah sebesar 1:3.

Pengukuran parameter fisika air meliputi $\mathrm{pH}$, salinitas, temperatur dan DO dilakukan setiap hari. Pengamatan parameter kimia air amonia dilakukan setiap 10 hari sampai akhir penelitian. Metode analisa ammonia menggunakan APHA (1990). Pengamatan parameter total hemocyte count (THC) dan kelangsungan hidup dilakukan pada akhir pemeliharaan. Analisa THC menggunakan metode Blaxhall dan Daishley (1973). Parameter frekuensi moulting diamati setiap hari mengacu pada metode yang digunakan oleh Vijayakumaran et al. (2010). Pengukuran biometri dilakukan setiap 10 hari sekali meliputi bobot, dan panjang total (Solanki et al. 2012).

Data frekuensi moulting, THC, laju pertumbuhan spesifik (LPS), pertumbuhan bobot pertumbuhan panjang dan kelangsungan hidup dianalisis secara statistik menggunakan analisis ragam (ANOVA) dengan software Minitab 16. Pada ANOVA dilakukan uji $\mathrm{F}$ pada selang kepercayaan $95 \%$ untuk menentukan ada atau tidaknya pengaruh perlakuan terhadap parameter uji. Apabila berpengaruh nyata maka dilakukan uji lanjut dengan metode Tukey.

\section{HASIL DAN PEMBAHASAN}

\section{Kondisi Kualitas Air Suhu}

Suhu selama penelitian cenderung stabil, yaitu berada dalam kisaran $26,9-28,1^{\circ} \mathrm{C}$ seperti yang dapat dilihat pada Gambar 2. Suhu optimal untuk budidaya lobster pasir yaitu $28^{\circ} \mathrm{C}$. Suhu optimum untuk pertumbuhan Panulirus argus berkisar pada suhu $25-27{ }^{\circ} \mathrm{C}$, Panulirus ornatus $30{ }^{\circ} \mathrm{C}$, Panulirus cygnus $25-26{ }^{\circ} \mathrm{C}$, dan Panulirus Interruptus $28{ }^{\circ} \mathrm{C}$ (Phillips dan Kittaka 2000). Menurut Kordi (2011), kisaran suhu optimal bagi biota laut adalah $24-32^{\circ} \mathrm{C}$. Secara keseluruhan, kondisi suhu selama pemeliharaan masih dalam rentang suhu optimum untuk budidaya lobster. 


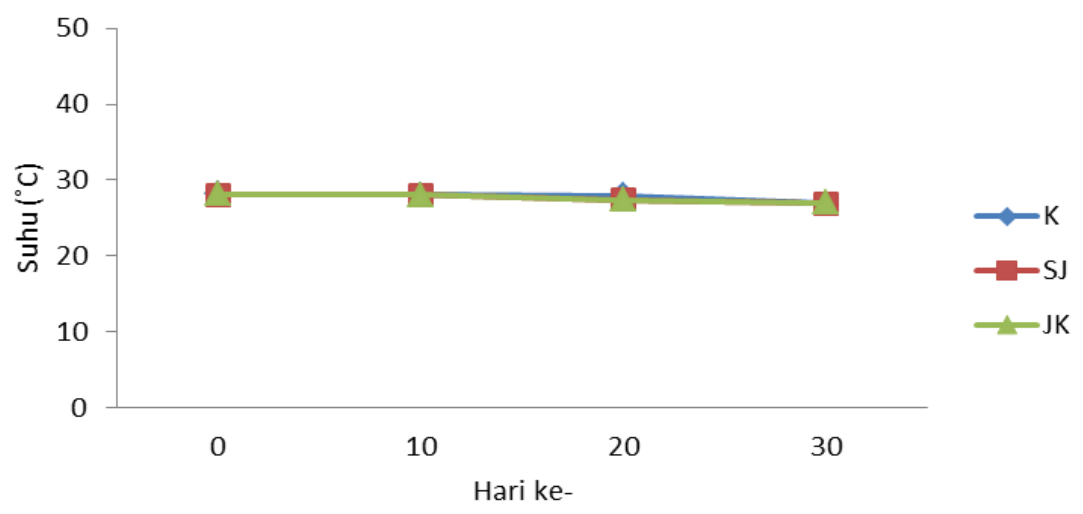

Gambar 2. Kondisi suhu selama penelitian. (K) kontrol, (SJ) sekat jaring, (JK) jaring keliling.

Figure 2. Temperature conditions during study. (K) control, $(\mathrm{SJ})$ nets partition, $(\mathrm{JK})$ nets lining inside the rearing tanks.

Sumber: hasil analisa data

\section{Oksigen Terlarut}

Oksigen terlarut selama pemeliharaan berfluktuasi pada kisaran 6,2-6,5 mg/L seperti terlihat pada Gambar 3. Menurut Phillips dan Kittaka (2000), konsentrasi oksigen terlarut minimum yang direkomendasikan untuk budidaya lobster adalah
$40-80 \%$ oksigen saturasi $(2,7-5,4 \mathrm{mg} / \mathrm{L})$. Kandungan oksigen terlarut optimum biota laut adalah 5-6 gram/L (Kordi 2011). Secara keseluruhan, kondisi oksigen terlarut selama pemeliharaan masih sesuai untuk budidaya lobster.

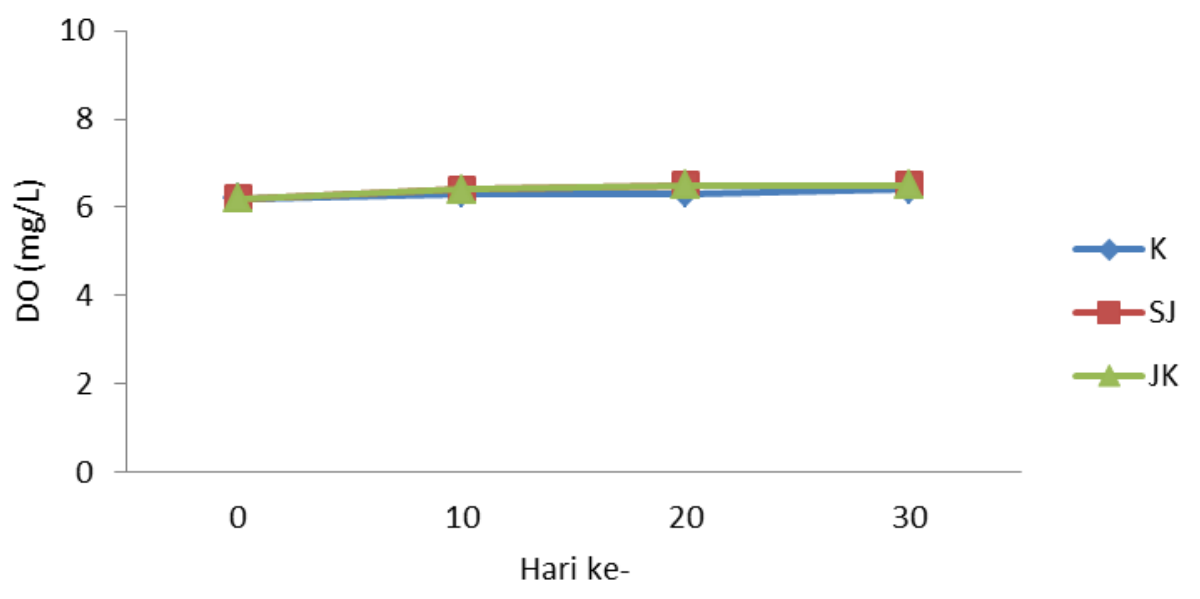

Gambar 3. Oksigen terlarut. (K) kontrol, (SJ) sekat jaring, (JK) jaring keliling.

Figure 3. Dissolved oxygen . (K) control, $(S J)$ nets partition, $(\mathrm{JK})$ nets lining inside the rearing tanks.

Sumber: hasil analisa data

\section{pH}

Kondisi pH selama pemeliharaan lobster cenderung stabil berkisar antara 7,9-8,2 (Gambar 4). Menurut Wickins dan Lee (2002), pH yang optimal pada pembesaran lobster pasir adalah 8,08,5 sedangkan $\mathrm{pH}$ yang optimal untuk biota laut adalah 7,6-8,7 (Kordi 2011). Kondisi pH selama pemeliharaan masih sesuai dalam kisaran $\mathrm{pH}$ yang optimal. 


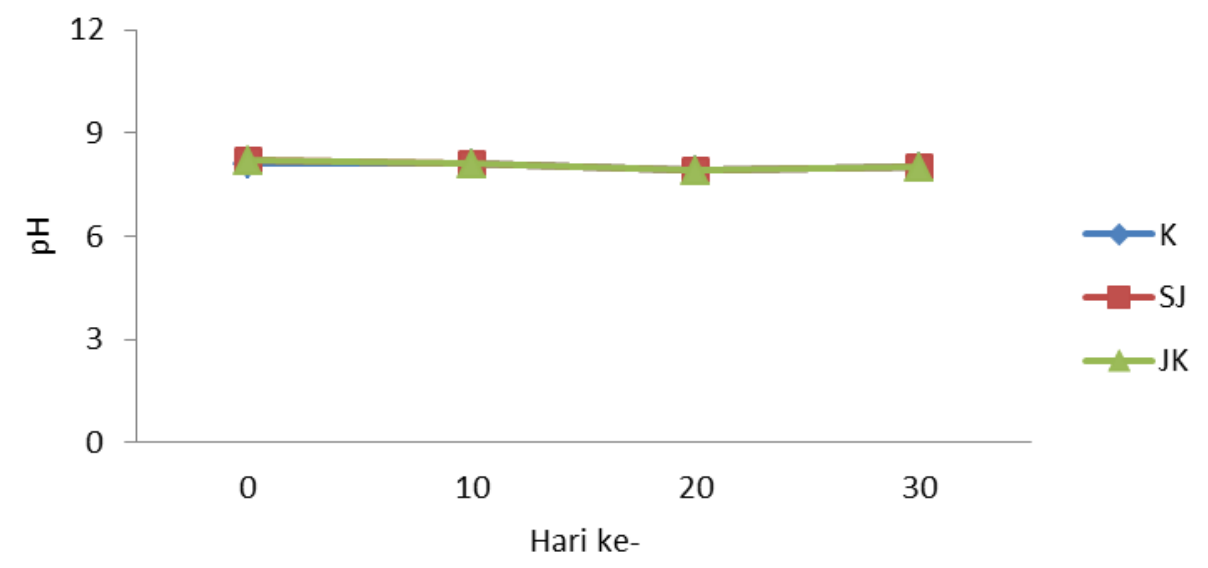

Gambar 4. pH air selama penelitian. (K) kontrol, (SJ) sekat jaring, (JK) jaring keliling.

Figure 4.Water pH during study. (K) control, (SJ) nets partition, (JK) nets lining inside the rearing tanks.

Sumber: hasil analisa data

\section{Salinitas}

Salinitas air selama pemeliharaan lobster berkisar antara 32-36 ppt, seperti dapat dilihat pada Gambar 5.

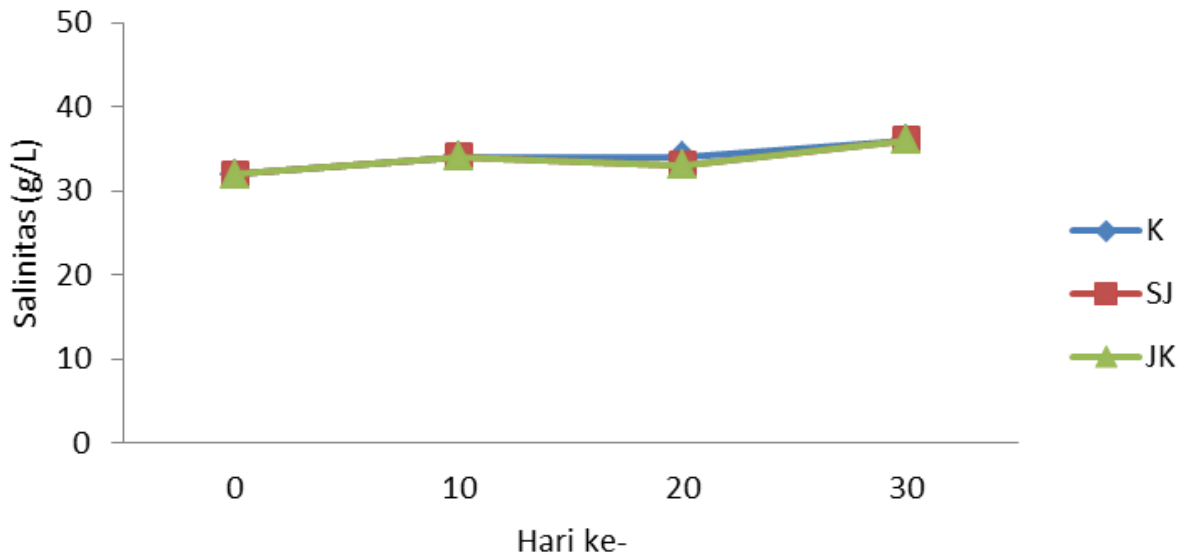

Gambar 5. Salinitas air selama penelitian. (K) kontrol, (SJ) sekat jaring, (JK) jaring keliling.

Figure 5. Water Salinity during study . (K) control, (SJ) nets partition, (JK) nets lining inside the rearing tanks. Sumber: hasil analisa data

Menurut Wickins dan Lee (2002), salinitas yang optimal untuk pemeliharaan lobster pasir adalah 32-36 ppt. Secara keseluruhan, kondisi salinitas selama pemeliharaan masih sesuai untuk budidaya lobster. Kondisi salinitas selama penelitian cenderung mengalami peningkatan. Hal ini disebabkan karena adanya proses evaporasi air kolam, sehingga volume air mengalami penurunan tetapi kandungan total padatan terlarut tetap. Hal tersebut menyebabkan nilai salinitas yang terukur mengalami peningkatan.

\section{$\mathrm{NH}_{3}$}

Kadar amonia $\left(\mathrm{NH}_{3}\right)$ air selama pemeliharaan berkisar antara 0,001-0,017 mg/L (Gambar 6). Kadar amonia tersebut masih memenuhi syarat untuk budidaya lobster. Menurut Wickins dan Lee (2002), nilai amonia yang ideal untuk kegiatan budidaya lobster adalah tidak lebih dari $0,1 \mathrm{mg} / \mathrm{L}$. 


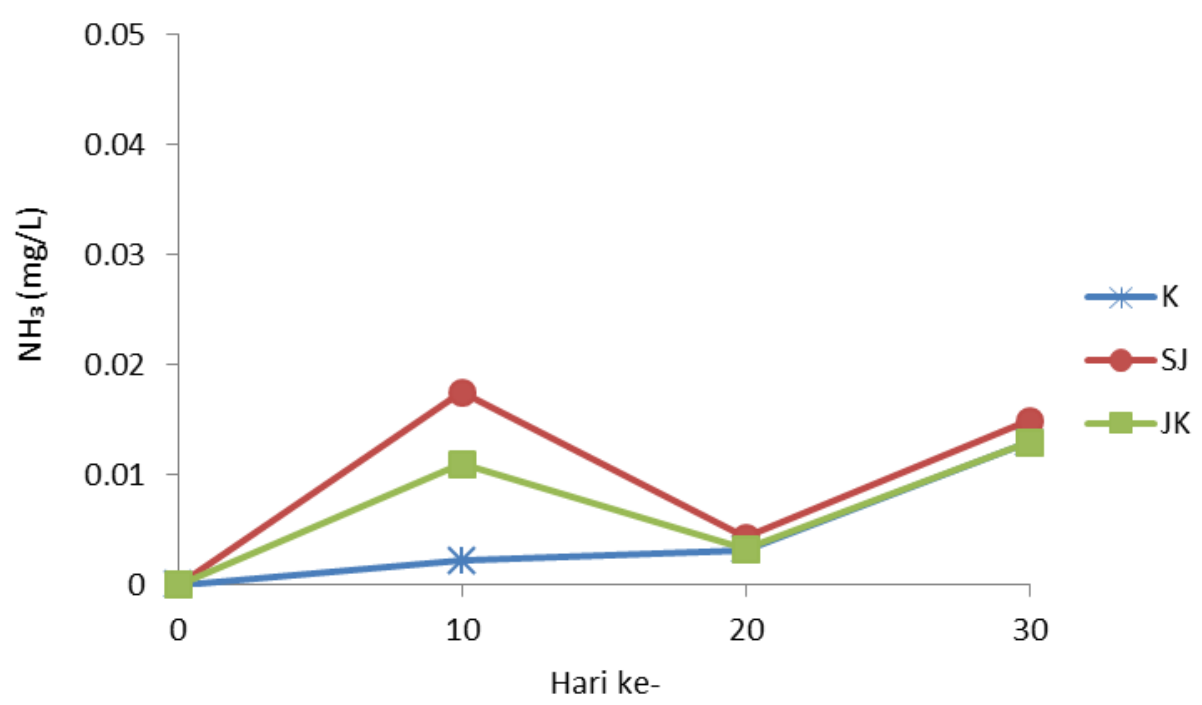

Gambar 6. Konsentrasi $\mathrm{NH}_{3}$ dalam air selama penelitian. (K) kontrol, (SJ) sekat jaring, (JK) jaring keliling. Figure 6. $\mathrm{NH}_{3}$ concentration in water during the study. (K) control, (SJ) nets partition, (JK) nets lining inside the rearing tanks.

Sumber: hasil analisa data

Kadar amonia air selama pemeliharaan cenderung meningkat. Kadar amonia pada hari ke-20 mengalami penurunan sampai kisaran 0,003-0,004 mg/L. Pada hari ke-30, kadar amonia cenderung mengalami peningkatan diduga terjadi karena akumulasi sisa pakan dan sisa metabolisme lobster. Buangan yang dihasilkan oleh organisme budidaya merupakan limbah yang berasal dari aktivitas metabolisme yang dapat menghasilkan amonia (Komarawidjaja, 2006). Kadar amonia air pada perlakuan menggunakan sekat jaring lebih tinggi dibandingkan perlakuan yang lain. Hal ini disebabkan pada perlakuan sekat jaring, jumlah lobster yang mengalami moulting lebih banyak (Gambar 7). Menurut Nazam et al. (2005), nafsu makan lobster akan menurun pada saat proses pergantian kulit. Hal ini menyebabkan sisa pakan pada perlakuan sekat jaring lebih banyak dibanding perlakuan lainnya. Sisa pakan ini menyebabkan peningkatan kadar amonia terlarut dalam air.

\section{Frekuensi Moulting}

Tingkat frekuensi moulting lobster selama masa pemeliharaan dapat dilihat pada Gambar 7. 


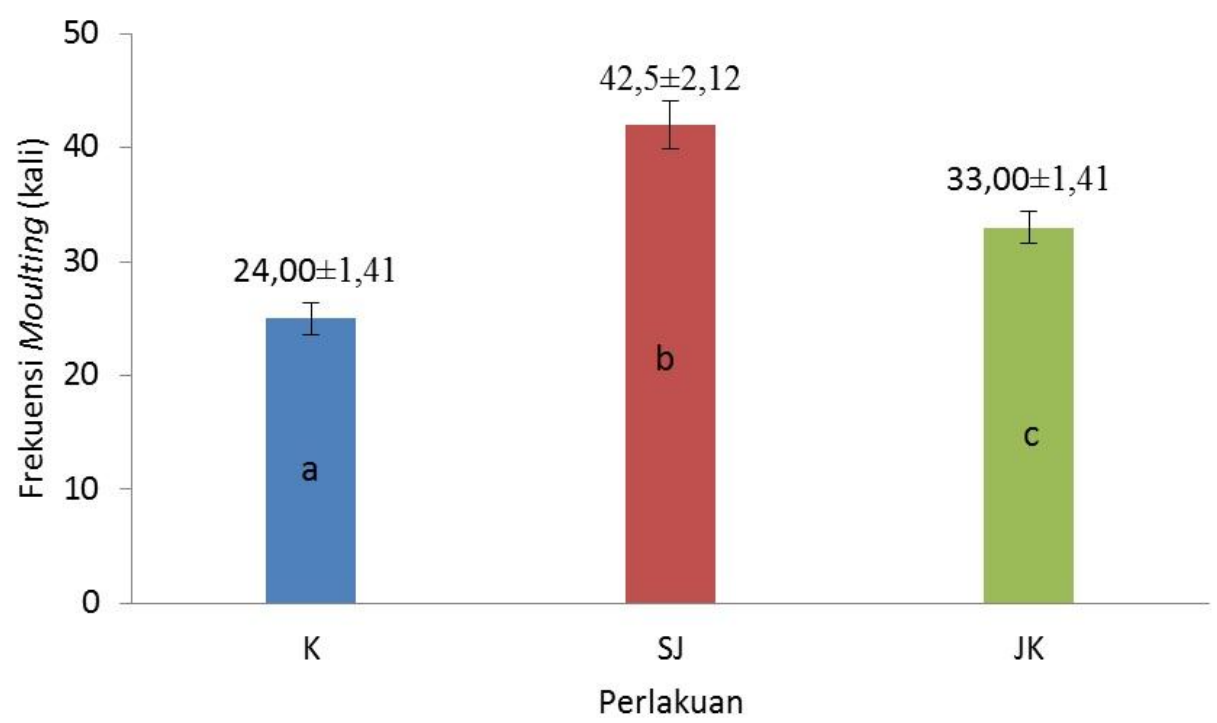

Gambar 7. Frekuensi moulting. (K) kontrol, (SJ) sekat jaring, (JK) jaring keliling. Huruf kecil yang berbeda dalam grafik menunjukkan beda nyata $(\mathrm{p}<0,05)$.

Figure 7. Moulting Frequency. (K) control, (SJ) nets partition, (JK) nets lining inside the rearing tanks. Different lowercase letters in the chart indicate real difference $(p<0,05)$.

Sumber: hasil analisa data

Jumlah moulting tertinggi terdapat pada perlakuan sekat jaring, yaitu $42,5 \pm 2,12$ kali selama pemeliharaan. Hasil analisis ragam menunjukkan penggunaan sistem jaring menghasilkan frekuensi moulting yang berbeda nyata $(p<0,05)$ dengan kontrol. Frekuensi moulting dapat dijadikan parameter pertumbuhan pada lobster. Pertumbuhan lobster akan terjadi setelah adanya proses pergantian kulit (moulting). Lobster

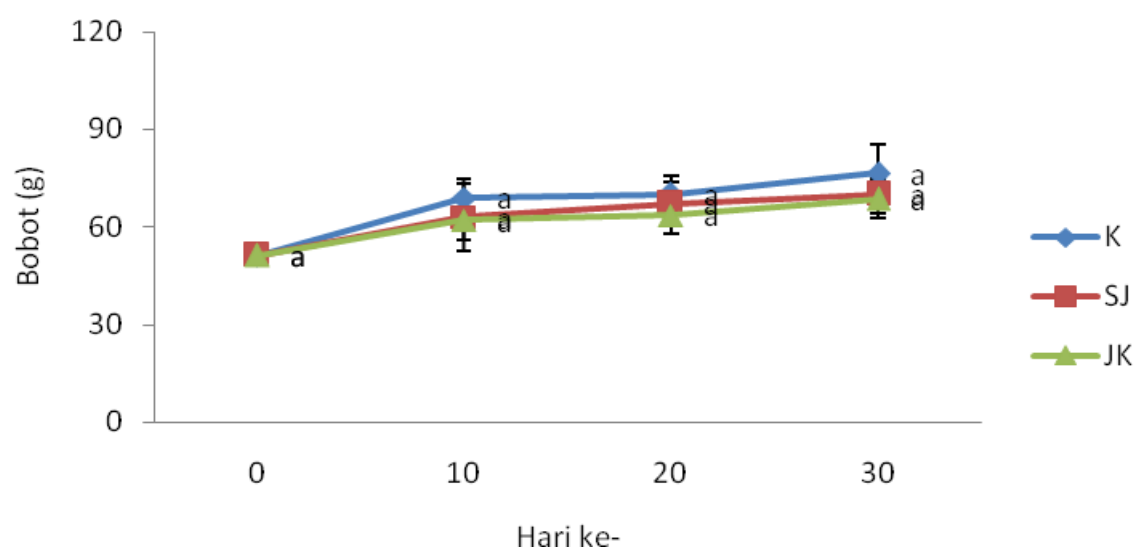

Gambar 8. Pertumbuhan bobot. (K) kontrol, (SJ) sekat jaring, (JK) jaring keliling. Huruf kecil yang berbeda dalam grafik menunjukkan beda nyata $(\mathrm{p}<0,05)$.

Figure 8. Weights measurement. $(K)$ control, $(S J)$ nets partition, $(\mathrm{JK})$ nets lining inside the rearing tank. Different lowercase letters in the chart indicate real difference $(p<0,05)$

Sumber: hasil analisa data 


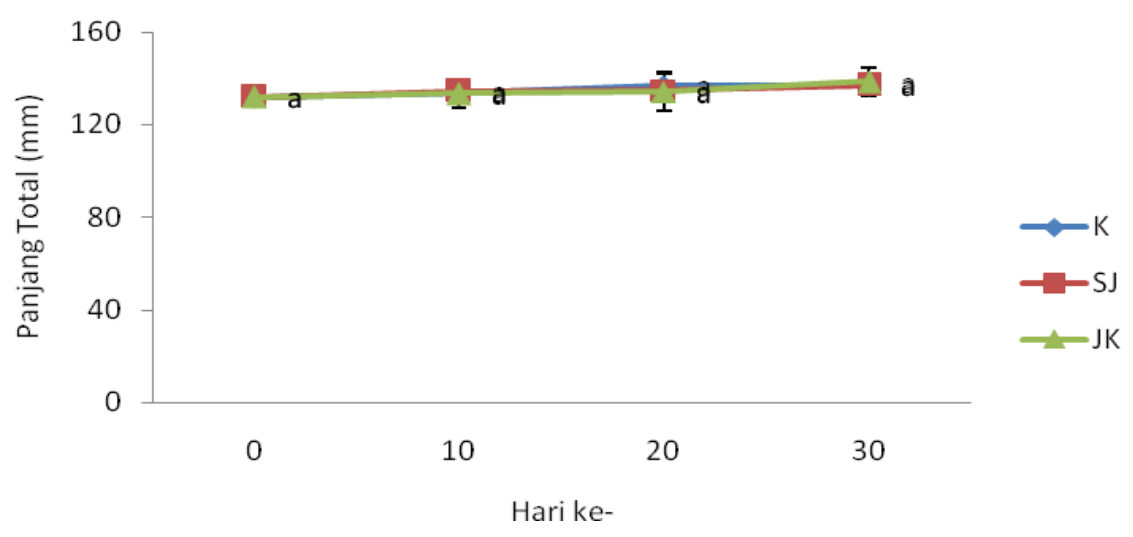

Gambar 9. Grafik panjang total. (K) kontrol, (SJ) sekat jaring, (JK) jaring keliling. Huruf kecil yang berbeda dalam grafik menunjukkan beda nyata $(\mathrm{p}<0,05)$.

Figure 9. Total length measurement. $(K)$ control, $(S J)$ nets partition, (JK) nets lining inside the rearing tanks. Different lowercase letters in the chart indicate real difference $(p<0,05)$.

Sumber: hasil analisa data

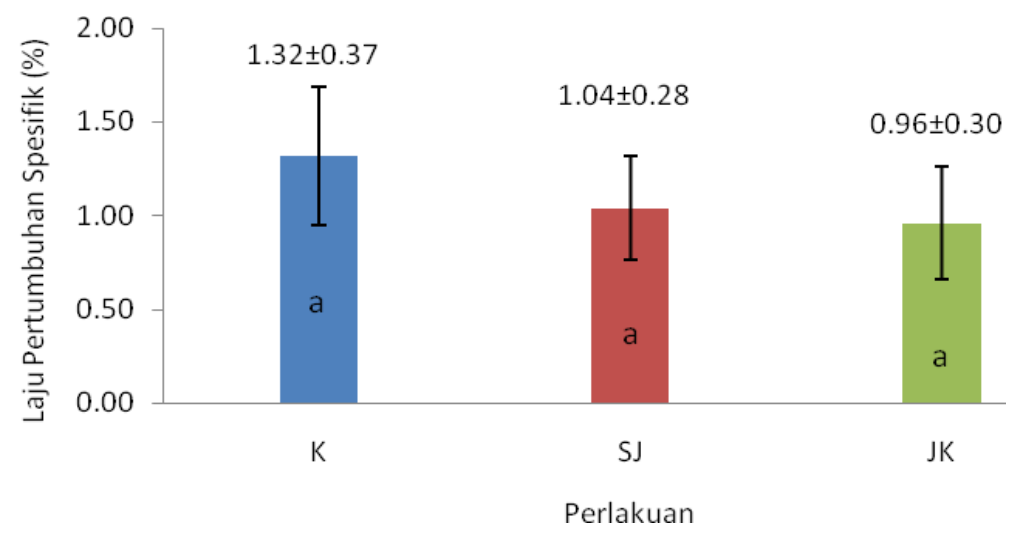

Gambar 10. Laju pertumbuhan spesifik. (K) kontrol, (SJ) sekat jaring, (JK) jaring keliling. Huruf kecil yang berbeda dalam grafik menunjukkan beda nyata $(\mathrm{p}<0,05)$.

Figure 10. Specific growth rate. $(K)$ control, $(S J)$ nets partition, $(\mathrm{JK})$ nets lining inside the rearing tanks. Different lowercase letters in the chart indicate real difference $(p<0,05)$.

Sumber: hasil analisa data

Pertumbuhan lobster tertinggi terdapat pada perlakuan kontrol. Hasil analisis ragam menunjukkan penggunaan jaring menghasilkan pertumbuhan bobot, panjang, dan laju pertumbuhan spesifik yang tidak berbeda nyata $(p<0,05)$. Pertumbuhan dipengaruhi oleh beberapa faktor, yaitu sifat genetik, kondisi fisiologis, dan lingkungan media pemeliharaan (Weatherley, 1972). Bobot, panjang, dan laju pertumbuhan spesifik pada perlakuan kontrol merupakan yang tertinggi, yaitu $66,7 \pm 1,41 \mathrm{~g}$, $134,92 \pm 2,11 \mathrm{~mm}$, dan $1,32 \pm 0,37 \%$. Hal ini disebabkan pada perlakuan kontrol terdapat potensi kanibalisme yang lebih besar, sehingga lobster mendapat asupan tambahan selain dari pakan yang diberikan. Adanya kanibalisme akan mengurangi populasi lobster, sehingga persaingan dalam perebutan pakan akan menurun dan lobster dapat memanfaatkan pakan dengan lebih baik. Hal ini sesuai dengan Cokrowati et al. (2012), yang menyatakan lobster dengan kepadatan rendah akan semakin efisien dalam memanfaatkan pakan yang diberikan.

\section{Respons Total Hemocyte Count (THC)}

Respons THC lobster selama pemeliharaan dapat dilihat pada Gambar 11, yaitu berkisar antara $8,97-9,55 \times 10^{6} \mathrm{sel} / \mathrm{ml}$. 


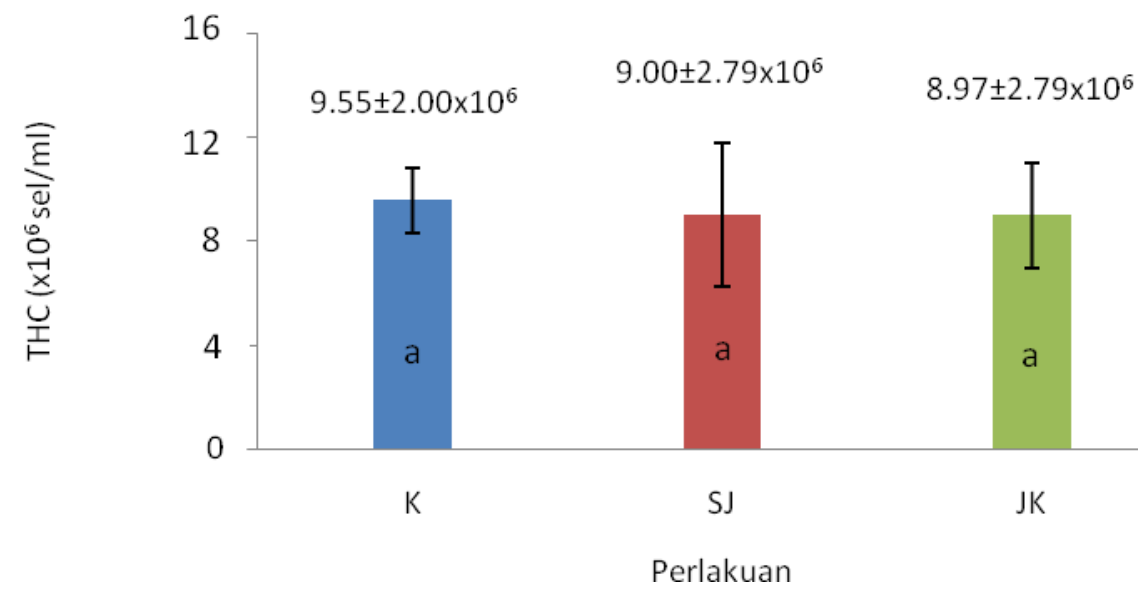

Gambar 11. Total Hemocyte Count. (K) kontrol, (SJ) sekat jaring, (JK) jaring keliling. Huruf kecil yang berbeda dalam grafik menunjukkan beda nyata $(\mathrm{p}<0,05)$.

Figure 11. Total Hemocyte Count. (K) control, (SJ) nets partition, (JK) nets lining inside the rearing tanks. Different lowercase letters in the chart indicate real difference $(p<0,05)$.

Sumber: hasil analisa data

Analisis ragam menunjukkan bahwa penggunaan jaring tidak menghasilkan nilai THC yang berbeda nyata $(p>0,05)$ terhadap kontrol. Menurut (Putri et al. 2013), jumlah hemosit di dalam hemolymph krustasea menunjukkan reaksi terhadap stresor lingkungan dan penyakit, sehingga dapat menjadi indikator status kesehatan krustasea dan adanya stresor lingkungan. Jumlah hemosit adalah salah satu parameter hemolymph yang paling sensitif dan konstan terhadap kondisi stres pada budidaya udang (Perazzolo et al. 2002). Penentuan jumlah hemosit dapat menjadi indikator awal bagi kondisi vitalitas juvenil krustasea secara dini (Hartinah et al. 2014). Konsentrasi THC terendah terdapat pada perlakuan jaring keliling, yaitu $8,97 \times 10^{6} \mathrm{sel} / \mathrm{ml}$ dan tertinggi pada perlakuan kontrol, yaitu $9,55 \times 10^{6} \mathrm{sel} / \mathrm{ml}$. Menurut Leland et al. (2013), peningkatan jumlah THC mengindikasikan adanya respon stress akibat handling dan respon terhadap perubahan lingkungan yang terjadi. Hal ini menunjukkan tingkat stres lobster pada perlakuan kontrol lebih tinggi dibanding perlakuan lainnya. Tingkat stress yang lebih tinggi pada perlakuan kontrol disebabkan lobster memiliki ruang gerak yang lebih sedikit dibanding perlakuan lainnya. Ruang gerak yang lebih sempit menyebabkan kontak antar lobster dan tingkat kanibalisme lebih besar, sehingga tingkat stres lebih tinggi dan kelangsungan hidup lebih rendah. Penggunaan jaring menghasilkan tingkat stress yang lebih rendah. Hal ini selain disebabkan ruang gerak yang lebih luas, penggunaan material yang berwarna gelap menghasilkan tingkat stres lobster yang lebih rendah. Menurut Rossong et al. (2011), juvenil lobster lebih menyukai selter yang terbuat dari bahan berwarna lebih gelap.

\section{Tingkat Kelangsungan Hidup}

Tingkat kelangsungan hidup dari masing-masing perlakuan pada akhir penelitian seperti dapat dilihat pada Gambar 12. berturut-turut adalah $75,00 \pm 0,00 \% \quad$ (kontrol), 82,75 $\pm 0,35 \%$ (sekat jaring), dan 92,50 $\pm 0,35 \%$ (jaring keliling). 


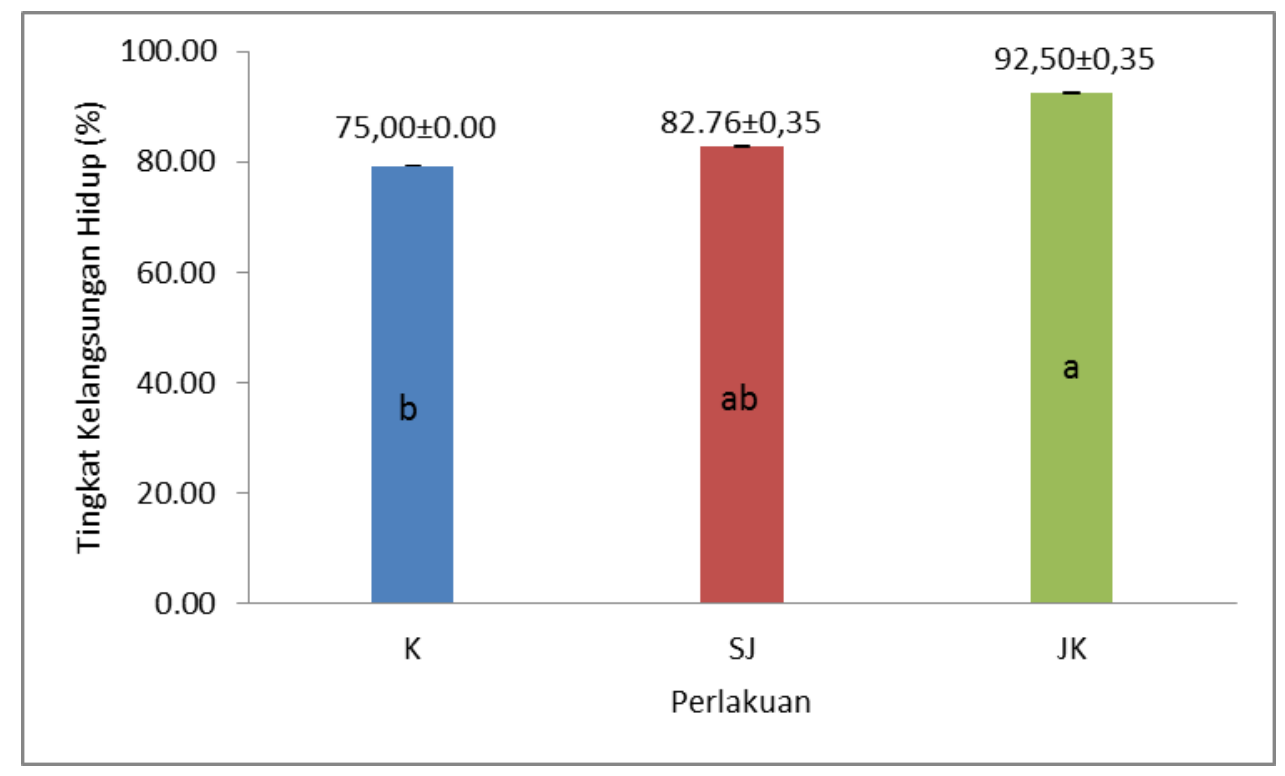

Gambar 12. Tingkat kelangsungan hidup lobster. (K) kontrol, (SJ) sekat jaring, (JK) jaring keliling. Huruf kecil yang berbeda dalam grafik menunjukkan beda nyata $(\mathrm{p}<0,05)$.

Figure 12. Survival rate of lobsters. (K) control, (SJ) nets partition, (JK) nets lining inside the rearing tanks. Different lowercase letters in the chart indicate real difference $(p<0,05)$.

Sumber: hasil analisa data

Hasil analisis ragam menunjukkan penggunaan sistem jaring keliling menghasilkan tingkat kelangsungan hidup yang berbeda nyata $(p<0,05)$ dengan kontrol. Penggunaan jaring memiliki tingkat kelangsungan hidup yang lebih baik. Hal ini disebabkan jaring yang digunakan berfungsi untuk memperluas ruang gerak lobster, sehingga kontak antar lobster lebih kecil. Kontak antar lobster yang lebih kecil menyebabkan tingkat kanibalisme yang terjadi selama pemeliharaan lebih rendah. Hal ini menyebabkan tingkat kelangsungan hidup lobster yang dihasilkan lebih tinggi.

\section{KESIMPULAN DAN SARAN}

Berdasarkan hasil penelitian, penggunaan sistem jaring pada budidaya pendederan juvenil lobster pasir Panulirus homarus tidak berpengaruh terhadap respons pertumbuhan, tetapi berpengaruh positif terhadap tingkat kelangsungan hidup juvenile lobster. Perlakuan terbaik terdapat pada penggunaan jaring keliling, dengan tingkat kelangsungan hidup tertinggi sebesar $91,38 \%$ dan laju pertumbuhan spesifik sebesar $0,96 \pm 0,3 \%$.

\section{DAFTAR PUSTAKA}

Adiyana K., Supriyono E., Junior M.Z., \& Thesiana L. (2014). Aplikasi Teknologi Shelter Terhadap Respon Stress dan Kelangsungan Hidup pada Pendederan Lobster Pasir Panulirus homarus. Jurnal Kelautan Nasional, 9(1), 1-9

Blaxhall P.C., \& Daishley K.W. (1973). Routine Haematological Methods for Use with Fish Blood. Journal of Fish Biology 5:577-581.

Cokrowati N., Utami P., \& Sarifin. (2012). Perbedaan Padat Tebar Terhadap Tingkat Pertumbuhan dan Kelangsungan Hidup Post Peurulus Lobster Pasir (Panulirus homarus) pada Bak Terkontrol. Jurnal Kelautan, 5(2), 156-166.

Drengstig A., \& Bergheim A. (2013). Commercial LandBased Farming of European Lobster (Homarus gammarus L.) in Recirculating Aquaculture System (RAS) Using a Single Cage Approach. Journal of Aquacultural Engineering, 53,1418.

Erlania, Radianta I.N., \& Sugama K. (2014). Dinamika Kelimpahan Benih Lobster (Panulirus spp.) di Perairan Teluk Gerupuk, Nusa Tenggara Barat: Tantangan Pengembangan Teknologi Budidaya Lobster. J. Ris. Akuakultur. 9(3),475-486. 
Fitrianto N.E. (2009). Laju Pertumbuhan dan Sintasan Spons Aaptos aaptos di Kolam Buatan Terkontrol [Skripsi]. Fakultas Perikanan dan Ilmu Kelautan. Institut Pertanian Bogor (ID).

Fujaya Y., Aslamyah S., \& Usman Z. (2011). Respons Molting, Pertumbuhan, dan Mortalitas Kepiting Bakau Scylla olivacea yang Disuplementasi Vitomolt Melalui Injeksi dan Pakan Buatan. Ilmu Kelautan, 16(4), 211-218.

Hartinah, Sennung L.P.L., Hamal R. (2014). Performa Jumlah dan Diferensiasi Sel Hemosit Juvenil Udang Windu (Penaeus monodon Fabr.) Pada Pemeliharaan dengan Tingkat Teknologi Budidaya Yang Berbeda. Jurnal Bionature, 15(2), 104-110.

Hastuti S., Mokoginta I., Dana D., \& Sutardi T. (2004). Resistensi Terhadap Stres dan Respons Imunitas Ikan Gurami (Osphronemus Gouramy, Lac.) yang Diberi Pakan Mengandung KromiumRagi. Jurnal Ilmu-Ilmu Perairan Dan Perikanan Indonesia, 11(1), 15 - 21.

James P. (2007). Lobsters do well in sea-cages: Spinny lobster on-growing in New Zealand. Bulletin Fish Research Agen, 20, 69-71.

Jussila J., McBride S., Jago J., \& Evans L.H. (2001). Hemolymph Clotting Time as an Indicator of Stress in Western Rock Lobster (Panulirus cygnus George). Aquaculture, 199, 185-193.

Khasani, I. (2008). Upaya Peningkatan Produksi dalam Usaha Pembesaran Udang Galah (Macrobrachium rosenbergii de Man). Media Akuakultur. 3(1), 25-30.

Komarawidjaja W. 2006. Pengaruh Perbedaan Dosis Oksigen Terlarut (DO) Pada Degradasi Amonium Kolam Kajian Budidaya Udang. Jurnal Hidrosfir. 1: 32-37

Kordi K., \& Ghufran H.M. (2011). Budi Daya 22 Komoditas Laut untuk Konsumsi Lokal dan Ekspor. Yogyakarta (ID): Lily Publisher.

Leland J.C., Butchera P.A., Broadhursta M.K., Patersonc B.D., \& Mayer D.G. 2013. Damage and Physiological Stress to Juvenile Eastern Rock Lobster (Sagmariasus verreauxi) Discarded After Trapping and Hand Collection. Fisheries Research, 137, 63-70.

Mohammed G., Syda-Rao S., \& Ghosh S. (2010). Aquaculture of Spiny Lobsters in Sea Cages in Gujarat, India. Journal of Marine Biological Assay, India, 52(2), 316-319.

Nazam M, Prisdiminggo, Surahman A. 2005. Penggunaan Shelter Buatan Untuk Meningkatkan Kelangsungan Hidup Udang Karang yang Dipelihara Dalam Keramba Jaring Apung. Seminar Nasional 2005, Balai Pengkajian Teknologi Pertanian NTB

Perazzolo, L.M., R. Gargioni, P.Ogliari and Margherita A.A. \& Baracco. (2002). Evaluation of Some
Hematoimmunological Parameters in the Shrimp Farfantepenaeus paulensis Submitted to Environmental and Physiological Stress. Departemen of Sel Biology, Embriology and Genetics, Centre of Biological Sciences, Federal University of Santa Ctarina, Florionopolis, SC, Brazil

Phillips B.F., \& Kittaka J, (2000). Spinny Lobster:Fisheries and Culture. Osney Mead (GB): Blackwell Science.

Putri F.M., Sarjito, \& Suminto. (2013). Pengaruh Penambahan Spirulina sp. dalam Pakan Buatan Terhadap Jumlah Total Hemosit dan Aktivitas Fagositosis Udang Vaname (Litopenaeus vannamei). Journal of Aquaculture Management anda Technology, 2(1), 102-112.

Rossong M.A., Quijon P.A., Williams P.J., \& Snelgrove P.V.R. (2011). Foraging and shelter behavior of juvenile American lobster (Homarus americanus): the influence of a nonindigenous crab. Journal of Experimental Marine Biology and Ecology 403:75-80.

Solanki Y., Jetani K.L., Khan S.I., Kotiya A.S., Makawana N.P., \& Rather M.A. ( 2012). Effect of stocking density on growth and survival rate of Spiny Lobster (Panulirus polyphagus) in cage culture system. International Journal of Aquatic Science 3(1).

Syda-Rao, George R.M., Anil M.K., Saleela K.N., Jasmine S., Kingsly H.J., \& Hanumanta R.G. (2010). Cage Culture of The Spiny Lobster Panulirus Homarus (Linnaeus) at Vizhinjam, Trivadrum Along The South-West Coast of India. Indian Journal of Fisheries, 57(1): 2329.

Thuy N.T.B., \& Ngoc N.B. ( 2004). Current Status and Exploitation of Wild Spiny Lobsters in Vietnamese Waters. Proceedings of a workshop held at the Institute of Oceanography, Nha Trang, Vietnam, 13-16. Australian Canberra: Centre for International Agricultural Research.

Verghese B, Radhakrishnan E.V., \& Padhi A. (2007). Effect of environmental parameters on immune response of the Indian spiny lobster, Panulirus homarus (Linnaeus, 1758). Fish \& Shellfish Immunology, 23,928-936.

Weatherley A.H. ( 1972). Growth and Ecology of Fish Population. London (GB): Academic Press.

Wickins J.F., \& Lee D.O.C. (2002). Crustacean Farming Ranching and Culture. Blackwell Science Ltd.

Yildiz H.Y., \& Benli A.C.K. (2004). Nitrite toxicity to crayfish, Astacus leptodactylus, the effects of sublethal nitrite exposure on hemolymph nitrite, total hemocyte counts, and hemolymph glucose. Journal of Ecotoxicology and Environmental Safety, 59, 370-375. 